\title{
REGULATION AND SUPERVISION SHADOW BANKING INSTITUTIONS WHICH IS POTENTIALLY GIVES SYSTEMIC RISK AS AN EFFORT TO GIVE LAW PROTECTION TO CONSUMERS (Study in Banyumas Ex-Residency) ${ }^{\Omega}$
}

\author{
Sulistyandari, MI. Wiwik Yuni Hastuti and Budiman Setyo H \\ Faculty of Law Universitas Jenderal Soedirman \\ E-mail: sulistyandari265@yahoo.co.id
}

\begin{abstract}
Shadow banking practice there is a tendency to increase, then the regulator should be set. Some cases have led to financial stability system disorders and cause systemic risk. This study aims to reveal weaknesses in the regulation and implementation of shadow banking institutions that have the potential for systemic risk and the protection of customers both normative and implementation in the Ex-residency of Banyumas. This study is a qualitative study with normative juridical approach and the study of law as the law in action, a social science studies that non-doctrinal and empirical. The results showed that the implementation of the supervision of shadow banking in the former residency of Banyumas potential harm to customers primarily in LJKNB shaped KSP/KJKS that provide services to nonmembers, LJKNB who misuse their permissions business activities, LJKNB that has not been incorporated, but no potential systemic. Factors law, law enforcement, facilities, people and culture affect the implementation of surveillance in the area of Ex-residency of Banyumas.
\end{abstract}

Keywords: regulation, supervision, shadow banking

\begin{abstract}
Abstrak
Praktek shadow banking ada kecenderungan terus meningkat, maka regulator harus mengaturnya. Beberapa kasus telah menimbulkan gangguan sistem stabilitas keuangan dan menimbulkan risiko sistemik. Penelitian ini bertujuan mengungkap kelemahan dalam pengaturan dan pengawasan terhadap lembaga shadow banking yang berpotensi risiko sistemik dan upaya perlindungan hukum nasabah baik secara normatif maupun dalam pelaksanaannya di wilayah Eks-Karesidenan Banyumas. Penelitian ini merupakan penelitian kualitatif dengan pendekatan yuridis normatif dan penelitian terhadap hukum sebagai law in action, merupakan studi ilmu sosial yang non-doktrinal dan bersifat empiris. Hasil penelitian menunjukkan bahwa pelaksanaan pengawasan lembaga shadow banking di wilayah eks Karesidenan Banyumas potensi menimbulkan kerugian kepada nasabah terutama pada Lembaga Jasa Keuangan Non Bank (LJKNB) yang berbentuk KSP/KJKS yang memberikan pelayanan kepada non anggota, LJKNB yang menyalahgunakan izin kegiatan usahanya, LJKNB yang belum berbadan hukum, namun tidak berpotensi sistemik. Faktor hukum, penegak hukum, sarana, masyarakat dan kebudayaan mempengaruhi pelaksanaan pengawasan di wilayah Eks-Karesidenan Banyumas.
\end{abstract}

Kata kunci: pengaturan, pengawasan, shadow banking

Introduction

Shadow Banking is a practice of financial services which imitates banking function in giving finance fund. It is 'bank bayangan' and in Indonesia this practice is booming, even tough some circles have opinion that shadow banking does not worry, but there is a tendency that it will increase, so the regulator should regulate it. ${ }^{1}$ Institutions which are included in shadow banking category such as: financial institution, a non-bank financial institution that is specially

$\Omega \quad$ This article is part of research Penelitian Unggulan Universitas Jenderal Soedirman with decree number Kept. 968/ UN23.14/PN.01.00/2015

Gayatri Rawit Angreni, "Resiko yang Membayangi Shadow Banking", Majalah Manajemen Resiko Stabilitas Perbankan, February 2013, Jakarta: Lembaga Pengembangan Perbankankan Indonesia, page 8 
established to finance; securities company, microfinance institutions that serve household consumers and informal sectors that is usually done by Saving and Loan Cooperative; multifinance company, financial service provider with the object of financing is productive and consumtive goods such as vehicle, household appliance, electronic, house, etc; a chain lottery club or arisan berantai (Ponzi Scheme).

Shadow banking case has occured in Indonesia which is detrimental to its members up to Rp.6 trillion conducted by Koperasi Langit Biru management. It is considered as fraud crime, and the doer has been punished, however the proceeds of crime which are detrimental the investor society not remained back and material losses are not counted. This tragedy resulted the lessening of public assurance in cooperatives and financial institutions in general. Financial institutions became difficult to mobilize customer funds. In United States Sub-prime mortgage, shadow banking case, caused trouble for the financial stability and caused systemic risk. $^{2}$

Recently, Indonesia has integrated institutions Financial Services Authority (Otoritas Jasa Keuangan/OJK), which has a strategic function of regulating and supervising financial institutions, banks and non-banks. ${ }^{3}$ It is expected the active role of OJK to handle shadow banking institutions which potentially systemic risk. Banyumas Ex-residency is a region of OJK Office of Purwokerto. Based on writer's observation, OJK Office of Purwokerto has done financial service institutions supervision recently. The obscurity in regulation and weak supervision or law enforcement against shadow banking institutions in addition it has a potential in systemic risk re-

\footnotetext{
Ibid, page 9

Nova Asmirawati, "Catatan Singkat terhadap UndangUndang Nomor 21 Tahun 2012 Tentang Otoritas Jasa Keuangan”, Majalah Legalitas, Vol.9 No.3, 2012, Jakarta: DJPP Kementerian Hukum dan HAM, page 449-558; Wiwin Sri Rahyani, "Independensi Otoritas Jasa Keuangan dalam Perspektif Undang-Undang Nomor 21 Tahun 2011 Tentang Otoritas Jasa Keuangan”, Majalah Legalitas, Vol. 9 No. 3, 2012, Jakarta: DJPP Kementerian Hukum dan HAM, page 361-372; Zulkarnain Sitompul, "Konsepsi dan Transformasi Otoritas Jasa Keuangan", Majalah Legalitas, Vol. 9 No. 3, 2012, Jakarta: DJPP Kementerian Hukum dan HAM, page 343-360.
}

sulting the lack of legal protection for customer.

This research discusses the regulation and the supervision of shadow banking institutions as an effort to give legal protection for customers and the implementation of shadow banking institutions supervision in Banyumas Ex-Residency. It is important, because it will reveal the weakness in regulation and supervision towards shadow banking institutions which is potentially systemic risk and an effort to give legal protecttion for customers both normatively as well as in the implementation in Banyumas Ex-Residency.

\section{Problems}

This journal discusses about: first, How is the regulation and supervision of shadow banking as an effort to give legal protection towards customers? and second, How is the supervision implementation of shadow banking institutions in Banyumas Ex-Residency?

\section{Research Methods}

This is a qualitative research with normative juridical approach and study of law as law in action, and it is non-doctrinal social study and empirical. Research location in jurisdiction of Banyumas Ex-residency. The data derived from primary data taken from those having relation with shadow banking institutions such as OJK, Dinperindagkop, Local Government or Pemda (Economic Section of Banyumas, Purbalingga, Cilacap and Banjarnegara), Community Empowerment Board (Badan Pemberdayaan Masyarakat), Institute of the Consumer Protection Organization (Lembaga Perlindungan Konsumen Swadaya Masyarakat). Secondary data such as laws, text books, scientific journals, the results of previous experiments, documents which have a relation with the experiment. The data collection method with documentation, interviews and observations. The data were analyzed by interpreting the data based on the norms and law theories especially financial services institutions law, civil law, administrative law and theory of law enforcement. 


\section{Discussion \\ Regulation and Supervision of Shadow Banking Institution as a Legal Protection to Wards Cus- tomers}

The term of Shadow banking also called Bank Bayangan, ${ }^{4}$ or Bank Gelap. Defines shadow banking is difficult because there is no consensus among the experts. ${ }^{5}$ According to the IMF definition, shadow banking is all financial activity, except traditional banking, which requires private and public regulations in their business activities. ${ }^{6}$ According to Nicola Ginneaoli, economists in the United States defines shadow banking as a financial intermediary, trade loans, investment funds and external financing risk free. ${ }^{7}$ According to Muhamad Amar Mohd Farid, shadow banking in Malaysia is defined as a system of credit intermediation that involves entities and activities outside the scope of the regulations of Bank Negara Malaysia (BNM). ${ }^{8}$ Shadow banking institution in Indonesia, generally defined as non-bank financial institutions that conduct banking practices, such as finance companies, private equity funds, retire funds, insurance, microfinance institutions (MFIs), the private pawnshops, and savings and loan cooperatives (Koperasi Simpan Pinjam/KSP).

According Schwachz cited by Ika Rosalia Rachmawati, because the shadow banking has not been defined clearly, so the characteristics would be tentative. Based on Schwachz's observations, the characteristics of shadow banking are: first, less regulated than the banking sector in general; second, if the banks are tightly

\section{Gayatri Rawit Angreni, Op. Cit, hlm.8-9}

Simin Gao dan Qianyu Wang, "Chasing the Shadow in Different Worlds: Shadow Banking and Its Regulation in the U.S. and China", Manchester Journal of International Economic Law, Vol. 11, Issue 3, 2014, Beijing: Tsinghoa University.

6 Alyssa Maharani, "Chinese Shadow Banking Institutions: Understanding Factors Contributing to the Systemic Risks of Trusts and Investment Corporations", Wharton Research Scolars Journal, Vol. 4, 2015, Pennsylvania: University of Pennsylvania.

7 Nicola Ginneaoli, Andrei Shleifer, Robert W. Vishny, “A Model of Shadow Banking", The Journal of Finance, Vol. LXVIII No. 4, August 2013, Cambridge: Harvard University.

8 Muhamad Amar Mohd Farid, "Monitoring shadow banking and its challenges: the Malaysian experience", The Service Industries Journal, Vol. 32 No. 5, 2013. Malaysian: Malaysia Institute of Statistic. regulated, then there is almost certainly penetration of the shadow banking; third, if the shadow banking company undertakes the intermediation function, the shadow banking company will boost its economy, but would have potential financial risks; and fourth, if the Shadow banking company left without a regulation, it will have an impact on the financial system. ${ }^{9}$

The problem is the practice of shadow banking is not regulated and closely monitored, it will be able to disrupt the system of financial stability, hence potentially systemic risks. Risk is defined as the potential causes of the events which can result in losses to the bank/financial services institution. According to the explanation of Article 37 of Law No. 10 Year 1998 (Banking Law), a bank is experiencing the dangerous condition of the banking system, if the condition of the banks deteriorated and the level of difficulty experienced by the bank in conducting business activities are not able to meet its obligations to other banks, so the turn will lead to a multiplier effect to the other banks. According to the Government Regulation in Lieu of Law 4 Year 2008 on the Financial System Safety Net (JPSK), systemic effect is that a difficult condition caused by a Bank, Non-Bank Financial Institutions, and/or other LKBB thus cause a loss of confidence in the financial system and national economy. Therefore, the practice of shadow banking is not regulated and closely supervised, it will be able to disrupt the financial stability and the potentially systemic risk. If LJKNB/LKBB conducting banking practice without regulation and supervision can result in losses, and the losses are not only on individuals, but it has a multiplier effect, causing a loss of confidence in the financial system and the national economy.

The essence of supervision is to prevent the earliest possible occurrence of irregularities, waste, fraud, obstacles, mistakes and failures in achieving the aims and objectives and the tasks of the organization, to create a con-

\footnotetext{
9 Ika Rosalia Rahmawati, "Penetrasi Praktek Shadow Banking Di Indonesia”, Jurnal Akuntansi Unesa, Vol. 1 No. 1, 2012, Surabaya: Universitas Negeri Surabaya.
} 
trol it needs elements as follows ${ }^{10}$ : first, there is a clear authority owned by regulatory authorities; second, there is a plan, wisdom, instruction, and provisions have been established and accepted as a tool for examining the implementation of the tasks/activities that will be monitored; third, supervision can be done on ongoing activities and also towards the results achieved from these activities; fourth, supervision ended with the arrangement of the final evaluation of the implemented activities and matching the achieve result with the plan, wisdom, instruction, and provisions have been established and accepted as a benchmark; and fifth, further supervision measures will be continued with follow-up both administratively and judicially. The institution authorized to supervise the shadow banking institution (LJKNB) is the OJK. It is based on the provisions of Article 55 paragraph (1) of Law No. 21 Year 2011, it started on December 31, 2012, the functions, duties and authority of the regulatory and supervisory activities of the financial services in Capital Markets, Insurance, Pension Funds, Financial Institutions, and the others Financial Service Institutions switched from Minister of Finance and Bapepam-LK to OJK.

Law regulations which regulate LJKNB such as: Law No. 11 Year 1992 concerning Pension Fund, Law No. 8 Year 1995 concerning the Capital Market, Law No. 40 Year 2014 concerning Insurance, Presidential Regulation No. 9 Year 2009 concerning Financing Institutions, Government Regulation No. 51 Year 2011 concerning Perum Pegadaian to Persero Pegadaian (concerning fiduciary managed in Civil Code), Law No. 2 Year 2009 concerning Indonesian Export Credit Agency, Presidential Regulation No. 19 Year 2005 concerning Secondary Mortgage Finance amended by Presidential Regulation No. 1 Year 2008, Law No. 25 Year 1992 concerning Cooperatives, Law No. 1 Year 2013 concerning Micro Finance Institutions. Regulations, regulated LJKNB, seem there are still some financial services institution that have not been regula-

10 Muchsan, 2007, Sistem Pengawasan Terhadap Perbuatan Aparat Pemerintah dan Peradilan Tata Usaha Negara di Indonesia, Yogyakarta: Liberty, page 38 ted in law such Financial Institution, Secondary Mortgage Finance and Fiduciary are only arranged in the form of presidential regulation and government regulation, it means that there is no equality in regulating LJKNB, in order there should be equality in regulating LJK NB, in order to provide protection and legal certainty for LJKNB and customers.

Some regulations have been issued by the OJK include POJK Number 10/POJK.05/2014 concerning the Assessment of Risk Level of NonBank Financial Services Institution (LJKNB). LJK NB in conducting business activities are required to apply the precautionary principle and risk management, in this case LJKNB required to assess risk levels at least once a year they are strategic risk, operational risk, assets and liabilities risk, management risk, governance risk, support funds risk, insurance risks specific to insurance and reinsurance companies, financing risks specific to the finance company in conducting business activities, for liability risk management is conducted surveillance/assessment by the OJK and assessment of the OJK is the probability of failure of LJKNB to fulfill their liability to customers or other parties. Supervision by the OJK conducted using evaluation in the report made by LJKNB about the results of the risk assessment. OJK assessment results are categorized in five levels of risk LJKNB they are: first, LJKNB Low risk level (0-1); second, LJK NB Medium Low risk level (> 1-1.5); third, LJK NB Medium High risk level (> 1.5-2); fourth, LJK NB High risk levels (> 2-3); and fifth, LJKNB High risk level (>3-4). In order to follow-up assessment risk, the OJK is authorized to: first, Ask LJKNB to make adjustments on an action plan; second, give written orders to LJKNB and/or a particular party; third, make the appointment of the statutory manager; fourth, stipulate the use of statutory managers; fifth, revoke the business license of LJKNB; and sixth, establish LJKNB dissolution. OJK authorized to provide the following sanctions: a written warning; fine is an obligation to pay a certain amount of money; obligation for the directors or the equivalent in LJKNB to undergo a refit and proper; restrictions on business activities; suspension of 
business; and revocation of business activities. In addition, the OJK also has issued: first, POJK No. 12/POJK.05/2014 concerning Licensing of Business and Institutional MFIs. second, POJK No. 13/POJK.05/2014 concerning the Implementation of Enterprise MFIs; third, POJK No. 14/ POJK.05/2014 concerning Development and Monitoring $\mathrm{MFI}$ as the implementing regulations of Law No. 1 Year 2013 concerning Microfinance Institutions ${ }^{11}$ and Government Regulation No. 89 Year 2014 concerning Interest Rates Loans Or Yield Financing And Wide Area Coverage Business MFI.

Based on the description of the laws of LJ KNB connected with OJK and PJOK such as POJK No. 10/POJK.05/2014 concerning the Assessment of Risk Level of Non-Bank Financial Services Institution (LJKNB), it needs a change in law regulation to be synchronized spesifically about who have authorization to conduct guidance and supervision, objective, methods, approach, follow-up after the supervision and sanctioning.

Doing the shadow banking institution supervision in law concept is in the frame to provide protection, which the law is formulated in the form of rights and obligations. Therefore, the rights and obligations, formulated normatively, should create legal protection for the parties, if it does not provide protection normatively, then there needs improvement in the law itself.

Law (rights and obligations) should also be implemented. if there are deviations in the implementation, then it needs to be enforced and evaluated the factors why there are deviations, so the objective of the law to achieve justice/protection for the parties can be achieved, as in the context of this research is the regulation and supervision of shadow banking institution, which aims for the protection of customers and the society in general, for that there needs to be a change in LJKNB law regulation for the protection of the customer/consumer.

11 I Gde Kajeng Baskara, Lembaga Keuangan Mikro Di Indonesia, Jurnal Buletin Studi Ekonomi, Vol. 18, No. 2, august edition, 2013, South Kuta Bali: Universitas Udayana.
The Implementation of the Shadow Banking Supervision in Banyumas Ex-residency

According to the study of administrative law, supervision is a part of the legal aspects of enforcement that its instrument include control and sanctions. Supervision is done towards citizens' compliance in order the rules which is obligating or something forbidden is not violated. Sanctions also a burden instrument.

The main problems of law enforcement located in the factors that may affect it. These factors are factors of its own law, law enforcement, they are the parties that make and apply the law. The factors supporting rule of law, society factors, are the environment in where they may apply or applied. Cultural factors, namely as a work of authorship, and the flavor is based on human initiative in social life. These five factors are closely interrelated and constitute the essence of the rule of law, also is a measure of the effectiveness of law enforcement. These factors have the neutral meaning, so that a positive or negative impact lies in the content of these factors. ${ }^{12}$

Based on the results of research in the area of Banyumas ex-Residency, there were 1527 LJKNB includes 236 LJKNB of legal entities and 1291 LJKNB unincorporated, of 236 LJKNB are incorporated distinguished 133 LJKNB a license and under the supervision of the FSA, and 103 LJKNB obtain a business license and under the supervision of Dinperindagkop. Mean-while number 1291 LJKNB are not legal entities do not get the regulation, and it is unclear who is authorized to grant an operating license and supervision.

Based on the research results, the supervision unit of 133 LJKNB which have a license and under the supervision of the OJK, in fact it still conducted supervision by central of OJK, because it is only a LJKNB 133 branch offices in the territory of the OJK Office of Purwokerto. Meanwhile there are two MFIs are still in the process of obtaining permits in Purwokerto OJK

\footnotetext{
12 Soerjono Soekanto, 2011, Faktor-Faktor Yang Mempengaruhi Penegakan Hukum, Jakarta: PT. Raja Grafindo Persada, page 5-9.
} 
office, so the OJK office Purwokerto yet to supervise the LJKNB.

Based on the research results, the supervision unit of 103 LJKNB which have a license and under the supervision of the data obtained Dinperindagkop there are some problems of monitoring results, among others, that there are some KSP/KJKS do not submit the progress reports of cooperative performance every month; not obey the applicable law, providing services to non-members. KSP/KJKS which do service to non-members means KSP/KJKS has been conducting shadow banking, generally performed by KSP/KJKS BMT (Baitul Maal wat Tamwil), for example BMT Dana Mentari Mu-hammadiyah Purwokerto in January 2014, the number of comparisons members with non-members is 178 : 11223 people. ${ }^{13}$ The contributing factors include: first, Dinperindagkop cannot monitor all activities of KSP/KJKS for a limited number of HR Supervisor Cooperative (Banyumas 5 people, Purbalingga 9 people, 5 people Cilacap, Banjarnegara 5); second, the understanding about cooperatives is still lacking; third, a small community of society such as cooperatives require BMT service, because it gives services more easily than the Bank; and fourth, political reasons, namely to get support from the community; HR capabilities and low discipline. Effort to face it, each Dinperindagkop doing it differently, such as their attitudes: first, considered to be violating the rules of cooperatives, then given advice/counseling, monitored and evaluated; second, Considered disobey the law on cooperatives, and then given a reprimand orally and in writing, shall be revoked its business license and revoked the certificates of cooperative legal entity; third, given 2 advices that is to be a member or discontinue the service to non-members; and fourth, doing coaching continuously. Thus there is no a firm stand from supervisors of Dinperindagkop to impose sanctions on the im- plementation of the shadow banking or legal violations committed by KSP/ KJKS

Towards the non-member which is not the members of KSP/KJKS who does shadow banking will not receive legal protection from LPS in the form of a backlog like banking customers. According to Law No. 1 Year 2013 of the MFI (MFI Act), KSP / KJKS BMT are required to be MFIs, so it will have the supervision of the FSA.

Based on the results of previous research data showed that, shadow banking institution happens because the perpetrators abuse the permission granted by Dinperindakop. The original permission is granted trade business $\mathbf{i}$ cense, then the license is used to conduct investment business activities of the community. For example in the case of CV. Berlian Artha Sejahtera (BAS) in Purbalingga conduct financial services in the form of investment with very attractive interest, so many investors are interested to invest, but after a company becomes large and a lot of customers, the company promised a standstill and the promised interest each month is not realized. While the permissions granted to the Dinperindagkop-KKPI to CV BAS is a business activity of trade in goods/ services major trading in telecommunication equipment and facilities. Director of BAS CV was charged and convicted for the "Bank Gelap". Victims who are disadvantaged on the activities of the Director CV BAS counted 1787 people, but the victim was not prosecuted losses to the Court, the reason unknowing victims of their rights and no assistance from legal counsel. ${ }^{14}$

Based on the research results, 1291 LJK NB have no legal entities, such as PNPM Pedesaan guidanced and supervised by Bapermas and Village (BKAD, BP-UPK, TV and TPP). Some issues related to the revolving fund PNPM implementation include: UPK with fictitious borrowing mode then embezzled the fund as happened embezzlement in Cilacap 275 million and in Pur-

13 Sintia Trisanti, 2014, Perlindungan Hukum Atas Dana Simpanan Calon Anggota Dan Anggota Baitul Maal Wat Tamwil (BMT) Dana Mentari Muhamadiyah Purwokerto, Thesis, Purwokerto: Postgraduate of Law Universitas Jenderal Soedirman.

14 Umum Prajitno, 2006, Tinjauan Victimologi Terhadap Korban Kehahatan Korporasi CV. BAS Di Purbalingga dalam Peradilan Sitem Peradilan, Thesis, Purwokerto: Postgraduate of Law Universitas Jenderal Soedirman. 
balingga 300 million. To BKD got control of PT BRI (Persero). ${ }^{15}$

Related with MFIs which have not get legal status associated with the enactment of MFIs Law, Purwokerto OJK Office in cooperation with the District Government (Banyumas, Purbalingga, Cilacap and Banjarnegara) collects a wide range of financial institutions at the village and district to give socialization about the law. Additionally District Government invites the OJK as the resource, because in January 2016, MFls that have not incorporated a legal entity is obliged to get legal entity in the form of PT (jointstock company) or cooperative form. There is a discourse that PNPM Pedesaan (Banyumas) will be used as the MFI with form PT, and BKD Banyumas used to form cooperative MFIs as well as BKD Cilacap in the process of becoming an MFI to form cooperatives. The obstacles in being MFIs include: compliance with licensing requirements; internal organization is not ready, the capital BKD/ PNPM for the establishment of cooperative/PT is still unclear about the ownership.

Based on the results of a study of customer protection in the region of Banyumas exresidency data showed that the legal protection to consumers is essentially LJKNB Law No. 8 Year 1999; Government Regulation No. 58 Year 2001 concerning the Development and Supervision of Consumer Protection; Government Regulation 59 Year 2001 concerning Consumer Protection Governmental Organization (LPKSM) as umbrella act; Several laws and regulations governing consumer protection as POJK 1/POJK. 07/2013 concerning Consumer Protection Financial Services Sector. However, POJK 1/POJK.07/ 2013 does not include the notion of consumer protection from the perpetrators of the MFI's financial services, so it is important for regulating complaints mechanism MFI depositors for their Sharia legal vacuum regarding customer complaints mechanism storage arrangements

15 Lis Djuniar dan Welly, "Analisis Program Nasional Pemberdayaan Masyarakat (PNPM) Mandiri Perkotaan Bagi Masyarakat Miskin di Lembaga Keswadayaan Masyarakat Kecamatan Seberang Ulu di Kota Palembang", Jurnal IImiah STIE MDP, Vol. 3 No. 1, September 2013, Malang: Universitas Muhamadiyah Malang. are harmed by the MFI. ${ }^{16}$ The implementation in the region of Banyumas ex-residency as follows: first, there are 5 LPKSM in the area Banyumas ex-residency, but the consumer society have not taken advantage of the LPKSM; second, there is no Badan Penyelesai Sengketa Konsumen (BPSK) in the territory of Banyumas ex-residency. Second, according to data from the Office on the implementation of the OJK Pur-wokerto POJK 1/POJK. 07/2013 has been dis-seminated to the public the contents of which are the rights and obligations of consumers, such as the rights of consumers on financial product information (benefits, risks, service), the right to education, the right to justice, the balance of the agreement, the rights of specific services to consumers with special needs, for damages consumers arising from errors and/or omissions, their officers and employees of business communities of the Financial services and/or third parties working for the interests of business communities services financial, consumer complaints servicing rights, the right to control consumer protection; third, the complaint in the Office of the OJK Purwokerto counted 144 complaints banking (most credit issues that $73 \mathrm{com}$ plaints), 10 complaints of insurance (most claims against one of the insurance companies who have been revoked license, which are 5 complaints), and a total of 26 complaints of financing (at most non-performing loans and request payment relief that 9 complaints); fourth, the attitude of the OJK to the complaint, which follow up the complaint if it meets the requirements, facilitated by arranging a bank and its customers, coordinating with other societies/ associations in order to minimize the complaints of consumers, to socialize with industry and various events to educate consumers and continue to Central office related to complaint IKNB.

Based on the analysis above can be illustrated that the lack or absence of oversight of shadow banking institution in the former resi-

\footnotetext{
6 Kaffi Wanatul Ma'wa, “Perlindungan Hukum Bagi Nasabah Penyimpan Lembaga Keuangan Mikro Syariah Yang Mengalami Kerugian Finansial", Jurnal Hukum, web: http//hukum.studentejournal.ub.ac.id, accessed at January $15^{\text {th }} 2015$.
} 
dency of Banyumas potential harm to customers/consumers. Potential losses occurring in LJKNB shaped KSP/KJKS who provide services to non-members (such as BMT), LJKNB who misuse their permissions business activities (such as CV BAS), LJKNB that have not been incorporated as a revolving fund in the PNPM, BKD, but potentially systemic risk, because of losses caused only on the individual, not to cause a multiplier effect resulting in a loss of confidence in the financial system and the national economy.

According Soerjono Soekanto, the main problem lies in the law enforcement factors that may affect it. ${ }^{17}$ Factors affecting the implementation of the surveillance or law enforcement agencies shadow banking in the region of ex Residency of Banyumas can be described as follows: first, Factor the law, that there is no similarity understanding about shadow banking institution, there is no similarity forms of regulation against LJKNB, no synchronization regulation of who is LJKNB authorized to conduct supervision and there is no law against consumer protection regulation in the rules governing LJKNB, no regulation and supervision of the LJKNB that have not been incorporated, so that it leads to a lack of legal protection of customer/consumer. Second, law enforcement factor, less assertive stance Supervisors to impose sanctions on LJKNB KSP/ KJKS who did shadow banking, so that it leads to a lack of legal protection of the Customer/Consumer. Third, factors which support the rule of law means that HR Supervisor of Dinperindagkop Banyumas Ex-residency for LJKNB KSP/KJKS is limited. Fourth, the society factor, that is still a lack of legal awareness of the community such as using financial services that clearly there is no legal certainty for protection. Fifth, cultural factors, that there is a public desire to get a quick and higher profit which are normal people think it can not be accepted, people's desire to get prompt service with easy requirements without thinking about the legal protection they will receive.

17 Soerjono Soekanto, op.cit., page 5-9.

\section{Conclusion}

Based on the analysis, it can be concluded that: first, On the regulation and supervision of shadow banking institutions, there is no similarity about the understanding of the shadow banking institution, there is no similarity forms of regulation against LJKNB, no synchronization regulation of who is authorized to supervise LJKNB and there is no protection regulation law towards consumers in the regulations governing LJKNB, there is no regulation and supervision of the LJKNB that have not been incorporated, so that these things can result in a lack of legal protection of customer/consumer. Second, The implementation of supervision shadow banking institutions in the Banyumas exresidency potentially give harm to customers primarily in LJKNB shaped KSP/KJKS who provide services to non-members (such as BMT), LJKNB who misuse their permissions business activities (such as CV BAS), LJKNB which has not been incorporated as a revolving fund in the PNPM, BKD, but not potentially systemically. Law factors, law enforcement, facilities, people and cultural influence in the supervision of Banyumas ex-residency.

\section{Suggestions}

The Writers suggests: first, needs a regulation that includes the definition of shadow banking institutions, in common forms of regulation, synchronization the regulation of LJKNB, there is a regulation and supervision towards LJKNB that have not been incorporated as an effort to give law protection against the Customer/consumer; and second, It needs a firm attitude of dinperindagkop supervisors to impose sanctions for violations of the law committed by KSP/KJKS, increasing the number of HR Dinperindagkop Supervisor in the Banyumas exresidency, required the continuous efforts of the local government in the Banyumas ex-residency therefore LJKNB that has not been incurporated to become MFI, there is education and information to the public about the potential risk of loss to businesses and consumers as an effort to the law protection. 


\section{Reference}

Amar, Muhamad and Mohd Farid. "Monitoring shadow banking and its challenges: the Malaysian experience". The Service Industries Journal, Vol. 32 No. 5. 2013. Malaysian: Malaysia Institute of Statistic;

Angreni, Gayatri Rawit. Resiko yang Membayangi Shadow Banking. Majalah Manajemen Resiko Stabilitas Perbankan, February 2013. Jakarta: Lembaga Pengembangan Perbankankan Indonesia;

Asmirawati, Nova. "Catatan Singkat terhadap Undang-Undang Nomor 21 Tahun 2012 Tentang Otoritas Jasa Keuangan". Majalah Legalitas, Vol.9 No. 3 Year 2012. Jakarta: DJPP Kementerian Hukum dan HAM;

Baskara, I Gde Kajeng. "Lembaga Keuangan Mikro Di Indonesia". Jurnal Buletin Studi Ekonomi, Vol. 18. No. 2. August 2013. South Kuta Bali: Universitas Udayana;

Djuniar, Lis and Welly. "Analisis Program Nasional Pemberdayaan Masyarakat (PNPM) Mandiri Perkotaan Bagi Masyarakat Mis-kin di Lembaga Keswadayaan Masyarakat Kecamatan Seberang Ulu di Kota Palembang". Jurnal Ilmiah STIE MDP, Vol. 3 No. 1. September 2013. Malang: Universitas Muhamadiyah Malang;

Gao, Simin and Qianyu Wang. "Chasing the Shadow in Different Worlds: Shadow Banking and Its Regulation in the U.S. and China". Manchester Journal of International Economic Law, Vol. 11 Issue 3. 2014. Beijing: Tsinghoa University;

Ginneaoli, Nicola. Andrei Shleifer. Robert W. Vishny. "A Model of Shadow Banking". The Journal of Finance, Vol. LXVIII No.4. August 2013. Cambridge: Harvard University;

Ma'wa, Kaffi Wanatul. "Perlindungan Hukum bagi Nasabah Penyimpan Lembaga Keuangan Mikro Syariah yang Mengalami Kerugian
Finansial". Jurnal Hukum, web: http//hukum.studentejournal.ub.ac.id. accessed at January $15^{\text {th }} 2015$;

Maharani, Alyssa. "Chinese Shadow Banking Institutions: Understanding Factors Contributing to the Systemic Risks of Trusts and Investment Corporations". Wharton Research Scolars Journal, Vol. 4. 2015. Pennsylvania: University of Pennsylvania;

Muchsan. 2007. Sistem Pengawasan Terhadap Perbuatan Aparat Pemerintah dan Peradilan Tata Usaha Negara di Indonesia. Yogyakarta: Liberty;

Prajitno, Umum. 2006. Tinjauan Victimologi terhadap Korban Kehahatan Korporasi CV. BAS Di Purbalingga dalam Peradilan Sistem Peradilan. Thesis. Purwokerto: Postgraduate of Law Universitas Jenderal Soedirman;

Rahmawati, Ika Rosalia. "Penetrasi Praktek Shadow Banking di Indonesia". Jurnal Akuntansi Unesa, Vol. 1 No. 1. 2012. Surabaya: Universitas Negeri Surabaya;

Rahyani, Wiwin Sri. “Independensi Otoritas Jasa Keuangan dalam Perspektif Undang-Undang Nomor 21 Tahun 2011 Tentang Otoritas Jasa Keuangan". Majalah Legalitas, Vol.9 No.3. 2012. Jakarta: DJPP Kementerian Hukum dan HAM;

Sitompul, Zulkarnain. "Konsepsi dan Transformasi Otoritas Jasa Keuangan". Majalah Legalitas, Vol.9 No.3. 2012. Jakarta: DJ PP Kementerian Hukum dan HAM;

Soekanto, Soerjono. 2011. Faktor-Faktor yang Mempengaruhi Penegakan Hukum. PT. Raja Grafindo Persada;

Trisanti, Sintia. 2014. Perlindungan Hukum Atas Dana Simpanan Calon Anggota Dan Anggota Baitul Maal Wat Tamwil (BMT) Dana Mentari Muhamadiyah Purwokerto. Thesis. Purwokerto: Postgraduate of Law Universitas Jenderal Soedirman. 